УДК 94(497.11)"1915/1918"

341.223.14(497.11)"1915/1918"

DOI https://doi.org/10.31212/tokovi.2020.3.mla.11-26

Оригинални научни рад

Примљен: 25. 3.2020.

Прихваћен: 1. 10. 2020.

Božica B. MLADENOVIĆ

Faculty of Philosophy, University of Niš

\title{
The Bulgarian Occupation Regime in Serbia 1915-1918 in the Light of Austro-Hungarian Documents
}

\begin{abstract}
This paper discusses the establishment and crucial aspects of the Bulgarian occupation system in the Kingdom of Serbia from 1915 to 1918. It is based on primary historical sources of German and Austrian origin and existing literature. The key characteristics of the occupying authorities, represented by the two military-inspection areas: Morava and Macedonia, are analyzed through the prism of the violations of the Hague Convention of 1908 (Convention with respect to the Laws and Customs of War on Land).

KEY WORDS: Serbia 1915-1918, the Bulgarian Occupation, Morava Military Inspection Area, Macedonia Military Inspection Area, Bulgarization (Denationalization), Economic Exploitation
\end{abstract}

The convention that was concluded between Germany, Austria-Hungary, and Bulgaria consisted of three documents. ${ }^{1}$ Two were signed in Sofia: the Treaty of Friendship and Alliance and the Secret Convention. The third document, the Military Convention, was signed in Germany, at German military headquarters in the palace of Pless (now Pszczyna in Poland). According to the agreement on joint military action and under the Secret Convention, Germany and Austria-Hungary guaranteed Bulgaria: "a) Macedonia, which is now Serbian and includes two Serbian zones 'disputed' and 'undisputed' as stated in the demarcation given by the Bul-

1 Andrej Mitrović, „Tajni ugovor između Centralnih sila i Bugarske od 6. septembra 1915”, Međunarodni problemi 3-4, 1978, 47-65. For more on this subject: Андреј Митровић, Србија у Првом светском рату, (Београд: Српска књижевна задруга, 2014). 
garian-Turkish agreement of 29 February/13th March 1912 [...]; b) Serbian territory east of the line: Morava river starting from the Danube to the confluence of the two Morava rivers, Bulgarian [South] and Serbian [Western], flowing watershed of these rivers, passing the ridge of the [Skopje] Montenegro, through the Kačanik Gorge, climbing the peaks of the mountain Šara, and reaching the border of the San Stefano Bulgaria following it further." ${ }^{\prime 2}$ The Convention gave Bulgaria the possibility to take over certain areas of Romania and Greece if they did not join the Central Powers. ${ }^{3}$

After the treaties of London (30 May 1913) and Bucharest (10 August 1913), the Kingdom of Serbia encompassed an area of $87,300 \mathrm{~km}^{2}$. The Secret Convention planned a territorial expansion on behalf of Bulgaria of $51,425 \mathrm{~km}^{2}$, which accounted for almost 59 percent of the prewar territory of the Serbian state. Before the war, 2,684.168 inhabitants, or 55.6 percent of the total population, lived on this territory. The territory of the Bulgarian state would rise to $163,425 \mathrm{~km}^{2}$ (based on its prewar size, the increase was 35 percent), and the population to 7,370,468 (an increase of 57.2 percent). ${ }^{4}$

In early December of 1915, Bulgaria demonstrated that its territorial claims at the expense of Serbia went beyond the agreement signed on 6 September $1915 .{ }^{5}$ On 4 December, Bulgarian commissioner in the German Supreme Command showed a letter from the president of the Bulgarian Government, which showed that the Bulgarians were "very much interested in exceeding the borders guaranteed by the convention in order to take over the whole railway line Smederevo - Niš". ${ }^{6}$ The formal step was made by King Ferdinand, Prime Minister Radoslavov and General-in-Chief Zhekov while visiting Kaiser Wilhelm II of Hohenzollern. On 10 February 1916, during a conversation between the Bulgarian and German representatives, the Bulgarian side requested the territories on the left bank of the Morava River, a part of Kosovo, and parts of Albania, which

2 Politisches Archiv des Auswartigen Amtes in Bonn (AA-Bonn, Oxfort) 0x. 97, PAbt, Deutschland $128 \mathrm{Nr} 8$ geheim, Bd. 18, Conventions secrete.

3 Милчо Лалков, Балканската политика на Австро-Унгарија 1914-1917, (Софија: Наука и изкуство, 1983); Živko Avramovski, Ratni ciljevi Bugarske i Centralne sile 1914-1918, (Beograd: Institut za savremenu istoriju, 1985); Wolfgang-Uwe Friedrich, "Bulgarien und die Mächte 1913-1915. Ein Beitrag zur Weltkriegs- und Imperialismusgeschichte", Quellen und Studien zur Geschichte des östlichen Europa, Bd. 21, (Stuttgart, 1985).

4 AA-Bonn, Ox. PAbt, Deutschland 128 Nr 8 geheim, Bd. 19.

5 Andrej Mitrović, Prodor na Balkan, (Beograd: Zavod za udžbenike, 1981), 394-405.

6 Андреј Митровић, „Стварање немачке окупационе зоне и аустроугарске управе у Србији (јесен 1915 - пролеће 1916)“, Историјски гласник, бр. 1-2, 1977, 26-28. 
had been occupied by Bulgarian troops. The Bulgarians then asked for territory with Smederevo, Smederevska Palanka, Rača, the districts of Levač and Temnič (so that the border line would go up to Kragujevac), Trstenik, Kruševac, Aleksandrovac, the peaks of Kopaonik Mountain, Priština, Prizren, and eastern Albania. ${ }^{7}$ These requirements were in full compliance with the Bulgarian aspirations to seize as much territory of Serbia, Montenegro and Albania as possible.

Before long, relations between Austria-Hungary and Bulgaria reached a serious crisis due to Bulgaria's claims to Kosovo and Albania. ${ }^{8}$ The Austro-Hungarian diplomats and military representatives in Sofia and Kyustendil, Bulgaria's Supreme Command headquarters, demanded, verbally and in written form, a stop to the establishment of Bulgarian administration in parts of Kosovo and Albania. The same requests were made by Emperor Franz Josef I, Minister Burian, and General Conrad von Hötzendorf, during the visit of King Ferdinand I, Prime Minister Radoslavov, and General Zhekov to Vienna and Teschen, the center of the Imperial and Royal High Command in mid-February of 1916. In Teschen, Ferdinand and Hötzendorf got into a serious quarrel. At that point, the Austro-Hungarian troops had crossed the line of demarcation with the Bulgarian army at many locations and occupied the territory held by the Bulgarians. This crisis deepened, especially after the armed resistance of a Bulgarian commander in Kačanik who had forced the imperial-royal troops to withdraw. ${ }^{9}$

By March, it was clear that Austria-Hungary and Bulgaria could not find a common ground. Therefore, Vienna accepted Field Marshal von Mackensen as a mediator. As a result of his personal visit to Sofia and his meetings with Ferdinand and Radoslavov, Bulgaria approved one of Germany's compromise plans proposed earlier. This paved the way for an agreement on the demarcation line between the Austro-Hungarian and Bulgarian commands signed on 1 April 1916. The agreement was based on the understanding that the area with the towns of Prizren and Priština would remain under Bulgarian rule, while Elbasan and Djakovica would fall under the Austro-Hungarian rule. Both sides accepted that the agreement was "exclusively military in nature" and that the two governments would be able to find another solution later. ${ }^{10}$ Thus, Bulgaria succeeded

$7 \quad$ Ibid.

8 Живко Аврамовски, „Бугарске претензије на анексију делова Косова у првом светском рату (1915-1916)“, Југословенско-бугарски односи у ХХ веку 2, 1982, 110-151.

9 Митровић, „Стварање немачке зоне“, 31-33.

10 Ibid. 
in getting the Central Balkan territories, which stretched far to the west of the line drawn in the treaty of 6 September $1915 .^{11}$

The various regulations that the Bulgarian authorities enacted following the occupation violated the stipulations of the Convention with Respect to the Laws and Customs of War on Land, known as the Hague Convention of 1908. According to the Hague Conventions, an occupying force had very limited powers on the seized territory. The $43^{\text {th }}$ article of the Rules clearly stipulates that the occupier is obliged to take all the measures in his power to establish and ensure, as far as possible, public order and safety, while respecting - unless absolutely prevented - the laws in force in the country. This meant that the municipal administration, judiciary, as well as educational, cultural, religious and charitable institutions could continue their work. Article 56 of the Convention precisely determines that the assets of these institutions are specially protected, so that even when they are state property they should be treated as private property. According to the former understanding and the applicable law, private property was sacrosanct and enjoyed special protection in relation to the state. It could become war spoils only if used for military purposes, but it had to be returned or compensated for at the peace settlement. According to Section b of Article 52, the issuing of a receipt for confiscated items, upon which the money was to be given, was an obligation. The occupier was entitled to public buildings, real estate, forests, and agricultural estates belonging to the state only as a usufructuary, i.e. he did not have the right to change their purpose. ${ }^{12}$

During the occupation regime in Serbia, the Bulgarian authorities especially violated Article 46 ("Family honor and rights, the lives of persons, and private property, as well as religious convictions and practice, must be respected."), Article 47 ("Pillage [of occupied zone] is formally forbidden") and Article 56 ("All seizure and deliberate destruction of his-

11 The boundary of this zone stretched on the west: the peak Kozjak, the Drenska Mountain, the mountain Golešnica, the Skopje Montenegro, the Kopiljak, the Bojnik near Prokuplje; and on the East: follows Vardar and Bregalnica, including Adžibegovo, Kviseli, Stracin, including the Kozjak Mountain, the peak Patarica, follows the Vlasina River to the Suva Mountain and passes Niš (excluded). In eastern Serbia, the line began on the Danube, $5 \mathrm{~km}$ south of Mihajlovac, went $7 \mathrm{~km}$ south of Štubik, $2 \mathrm{~km}$ south of Popovac, then on the North, touching Luke, Krivelj, Bor, Valakonje, Soko Banja, Aleksinac, Korman (all these points excluded). Митровић, „Стварање немачке зоне“, 32.

12 Момир Милојевић, „Повреде Хашких и Женевских конвенција у Србији““, Србија 1917. године, ур. Славенко Терзић, (Београд: Историјски институт САНУ, 1988), 21-35. 
toric monuments, works of art and science, is forbidden, and they should be specially protected"). ${ }^{13}$

The task of the occupation authorities established on the territory of Serbia was twofold: first, to ensure the possessed territories and natural resources for the war economies of the winning countries, and second, to ensure the realization of plans each of these countries had, on the permanent acquisition of territories upon establishing peace. Therefore, the occupation authorities were exceptionally brutal in political life, attacking the patriotic and national feelings of the population and excessively exploiting their economic resources.

The Bulgarians structured the internal organization of the Morava Military Inspection Area to match the provisional conditions imposed by the war, but also with regard to the intention of permanently keeping these territories. It was a combination of military and civil administration. The role of the military was crucial and the highest military and civilian authority was in the hands of the military governor-general. The first governor was Major General Kutinčev. The area was divided into six districts: Požarevac, Negotin, Zaječar, Ćuprija, Niš and Vranje (which included the Pirot district). The bureaucracy, especially the managerial staff, as well as mayors were from Bulgaria.

At the beginning of 1916, Austria-Hungary opened a consulate in Niš and sent a consular representative to Skopje. The embassy in Sofia represented the immediate higher authority of these institutions. ${ }^{14}$ Soon after, it appeared that the occupying authorities were attempting to implement a quick and thorough Bulgarization, regardless of the means. Officers and teachers started arriving from Bulgaria, becoming the striking force of Bulgarization, together with the armed forces. Measures of denationalization were primarily directed against the Serbs. On 20 Febru-

\section{Ibidem.}

14 For this paper we have used primary historical sources of German and indirectly Bulgarian origin. These sources are material from archives of Bulgarian allies, Austro-Hungary and Germany: Haus-, Hof- und Staatsarchiv (HHStA-Wien), Kriegsarchiv (KA-Wien), Politisches Archiv des Auswartigen Amtes in Bonn (AA-Bonn, пописник Oxfort). Funds in mentioned archives maintain very important testimonies for our topic. Some of them are of Bulgarian origin - correspondence of the Bulgarian government and the Bulgarian occupation authorities in Serbia on current affairs with the Austro-Hungarian and German authorities. Reports of various personnel of the two empires (diplomatic and consular, military, intelligence, economic and propaganda and cultural) are of particular interest for historians. This material contains statements of the Bulgarian official circles to their allies and their perception of current events. 
ary 1916, Colonel von Lustig, an Austro-Hungarian liaison officer at the headquarters of the German $11^{\text {th }}$ Army, wrote a confidential report to his supreme command: "The Bulgarians do not fail to take advantage of their occupation of eastern Serbia and Macedonia. They introduced their new administration in a ruthless and brutal manner [...]. The process of Bulgarization had two main directions: the destruction of the upper and middle classes of the local population and the enforced introduction of the Bulgarian language."15

One of the first measures undertaken was the mass deportation of adult males. On 14 December 1915, the governor-general ordered "all soldiers from 18 to 50 years of age who have served in the Serbian Army, all officers, former teachers, priests, journalists, former deputies, military officers, and all suspicious persons" to be captured and interned. ${ }^{16}$ However, during the first few months, the Bulgarians carried out mass executions under the guise of deportation. People were arrested and allegedly deported to Bulgaria, while in fact they were killed on the way. Colonel von Lustig was informed about that and he reported the following: "It is known that most of the Serbian intelligentsia, i.e. functionaries, teachers, priests and others, withdrew with what was left of the Serbian Army, but a certain number of them gradually started to return for psychological or material reasons. Here, in [Bulgarian]-occupied territory, it is virtually impossible to find either them or those that did not flee; they have 'gone to Sofia,' as the new Bulgarian saying goes. These men were handed over to Bulgarian patrols (usually komitas) as suspects without any judicial procedure, with the order that they should be 'taken to Sofia.' The patrols usually return the next day without them. Whether they are taken 20 or 200 kilometers, it is all the same. The patrols pack up spades, disappear into the mountains and quickly return, but without the prisoners. Bulgarian officers do not even try to conceal the executions, they boast about them." ${ }^{17}$

At the end of 1918, immediately after the war, the International Inquiry Committee found that at least a hundred Serbian priests had been killed in this way in the regions of Niš, Zaječar, and Surdulica, and that the bishop Vićentije and his deacon Cvetko had been killed in the Kačan-

15 Haus-, Hof-und Staatsarchiv- Wien (HHStA), Politische Abteilung I, K. 976, an attachment to the letter to the Supreme Command to the Ministry of Foreign Affairs 26 February 1916.

16 Миливоје Перовић, Топлички устанак, (Београд: Слово љубве, 1971), 48.

17 HHStA-Wien, PA I, K. 976. 
ik Gorge ${ }^{18}$ The invaders also terrorized the relatives of the victims, plundering some of them. Colonel von Lustig reported that evil did not, by any means, end with "sending the men to Sofia," and that the relatives or heirs of the victims were also killed. ${ }^{19}$

The occupying authorities declared a new "Property Law" by which they seized all movable and immovable property of persons who were not in the same place as their assets at the time the Bulgarian troops entered. The law also affected persons who had their property in several different places and they could not be in all of them at the same time. Colonel von Lustig commented: "In any case, such measures systematically impoverish the wealthy classes, [...]"20

Although in the spring of 1916, the brutal terror began to subside, the violence did not stop. The deportation of undesirables still continued. In mid-September, the Austro-Hungarian Consul Kolrus informed Baron Burian, the foreign minister of Austria-Hungary, that "although the mass internments by the Bulgarian side are not conspicuous, the male civilian population was still being sent quietly and unobtrusively, usually at night, to Bulgaria." ${ }^{21}$ Deportation and various kinds of violence were aimed at the peasantry, because practice had shown that Serbian national consciousness was deeply rooted in all layers of Serbian society.

The use of Serbian personal names, signs, language, and script had been prohibited from the very beginning of the occupation. Colonel von Lustig wrote in a report: "Just a few weeks after the fall of Niš, there could not be found a single Serbian inscription on the streets or stores. The surnames Petrović, Marković, Živković became Petrov, Markov, Živkov in a single swoop." ${ }^{22}$ At the end of July of 1916, the Austro-Hungarian consul in Niš, Kolrus, reported to his superiors that the Bulgarians were implementing "scarce cultural resources" as a part of their policy of denationalization and that "except for the introduction of Bulgarian schools, it is not possible to specify any other institution of this kind."23 Upon the

18 Documents relatifs aux violations des conventions de La Haye et du Droit international en general commises de 1915-1918 par les Bulgares en Serbie occuppée, 1-3, (Paris: Français Cartonne, 1919); The Enemy in Serbia, Documents Relative to the Bulgarian Atrocities 1915-1918, (Paris, 1919); R. A. Reis, A. Bonnassieux, Requisitoire contre la Bulgarie, (Paris: Librairie Bernard Grasset, 1919).

19 HHStA-Wien, PA I, K. 976.

20 Ibidem.

21 Ibidem, report from Niš on 16. September 1916.

22 HHStA-Wien, PA I, K. 976, an attachment to the letter to the Supreme Command to the Ministry of Foreign Affairs 26. February 1916.

23 HHStA-Wien, PA I, K. 976, report from Niš on 22. July 1916. 
occupation, some primary schools were opened and worked during the spring of 1916. The language used was exclusively Bulgarian, and Serbian children - schoolchildren were given Bulgarian names and surnames during the registration. The only subject taught seriously was the Bulgarian language, while everything else was only propaganda focused on the consciousness of young generations who were to "become" Bulgarians. At school celebrations children were encouraged to express their satisfaction at "regaining Bulgarian nationality."

From the autumn of 1916 and during 1917 new elementary schools were opened, as well as high schools in several towns. Teaching was in Bulgarian and entirely conformed to Bulgarian propaganda, while attendance was obligatory for all Serbian children. In the occupied territories of Serbia, books were printed and distributed among the population free of charge for the purpose of this political and educational propaganda. Niš schools showed documentaries about "the Bulgarian Pomoravlje." A number of Bulgarian university professors and ethnologists, historians, and geographers were in charge of developing the ideological basis for Bulgarization. ${ }^{24}$

In June of 1917, Moravski Glas, the organ of the occupying administration, was founded in Niš. Bulgarian officers had the final word in editing and soon the editorial office had become a kind of propaganda headquarters. Somewhat later, a cultural and artistic association called "Moravsko Društvo" was initiated. At the end of 1917, it began with organized work. In the beginning, its activity was reduced to recruiting male youth under the age of 20 for preparing tamburitza concerts. The next step was establishing the orchestra. The vice-consul reported: "Under the influence of certain young police agents, who purposely joined this association, the orchestra gradually turned into an organized body of over 50 young 'New Bulgarians' in the service of the political police and propaganda." ${ }^{25}$ In that way a number of "young people eager to live life" and "had nothing to do with politics" had been recruited. By joining the orchestra, they "gained some freedom, such as the right to move at night." The "Moravsko Društvo" eventually started becoming involved in economic activities and its activists founded a trade cooperative. Its members were given a monopoly to import various goods from abroad, on condition that they declared themselves Bulgarians. ${ }^{26}$

\footnotetext{
24 Ibidem.

25 HHStA-Wien, PA I, K. 976, report from Niš on 22. July 1916.

26 Ibidem.
} 
A Morava People's Education Committee was established in Sofia to monitor the entire propaganda activity. Releasing prisoners, returning from deportation or condoning the death penalty were measures often applied when those concerned and their families declared themselves as Bulgarians. The authorities invested a lot of effort and energy in order to compel the population to declare themselves as Bulgarians in various petitions to King Ferdinand, Prime Minister Radoslavov, and the Bulgarian authorities in general. These addresses were usually written by the occupation authorities, or were received pre-written from Sofia. The local officials were asked to gather signatures, as many as possible, by force if necessary. ${ }^{27}$

The headquarters of the Macedonia Military Inspection Area was in Skopje. This area encompassed the following districts: Skopje, Kumanovo, Tetovo, Štip, Tikveš (Kavadar), Bitolj, Ohrid, Prizren, and Priština. The occupation authorities also sought to impose Bulgarization by any means necessary. Sometimes they went to the extreme and practiced procedures considered ridiculous by their Central Power allies. Colonel von Lustig thought it bizarre that the mosque minaret and the bell tower of the Orthodox Church in Skopje were "painted red-green-white, from top to bottom." ${ }^{28}$ The new authorities, relying on pro-Bulgarian elements of the local population and personnel that had arrived from Bulgaria, tried to intensify their propaganda through the press, publications, public lectures, schools and cultural associations, creating a new political and ideological situation in Macedonia and Kosovo. The Austria-Hungarian Supreme Command's assessment of the actions of the Bulgarian occupation authorities in Kosovo reads: "As everywhere in Macedonia, the action must be directed toward converting the country into a purely Bulgarian land, at the cost of turning it into a Bulgarian desert" and "to carry out Bulgarization by fire and sword."29

The Bulgarian occupying authorities easily gained power over the deeply confused and extremely unhappy Serbs. ${ }^{30}$ According to Austro-Hungarian sources, from Macedonia, they were sent to internment to Bulgaria or they emigrated to the Governorate of Niš. In Kosovo, the Bulgarian

27 Ibidem, K. 976, report from Niš on 16 May, 11 July and 13 November 1917.

28 HHStA-Wien, PA I, K. 976, an attachment to the letter to the Supreme Command to the Ministry of Foreign Affairs on 26. February 1916.

29 Kriegs Archiv-Wien (KA), Op. Abt. Nr. 40904, Baden 20 Jun 1917.

30 HHStA-Wien, PA I, K. 976, 4 March 1917, No. 17500 (and the telegram on 3 March 1917, in attachment), telegram No. 343/1 on 28 March 1917, 20 March 1917, No. 18193. 
violence forced the Serb population into complete submission. The Austro-Hungarian Supreme Command received a report: "It seems to me that the Serbs have already become harmless. It seems that a significant part of the population can be assimilated really quickly, while the intelligentsia has largely been destroyed, and partly deported and interned in Bulgaria or in the 'Morava' district." 31 The Albanians and Turks were more difficult to handle since they resisted stubbornly. Therefore, they felt the "benefits" of the Bulgarian authorities on their own skin. The measures introduced can best be described by the fact that they were attached to labor groups made of hungry men forced to do hard physical labor. An eyewitness testified to skeletons falling dead from hunger during the work. The next person in line would replace the dead man immediately. ${ }^{32}$

The first sentence of a report by Vice-Consul Has, written several days after the Bulgarian occupation, describes precisely the result of Bulgaria's efforts to denationalize the occupied territories: "The 'liberated Bulgarians in Morava' truly rejoice to see their 'liberators' leave." ${ }^{33}$ All the measures applied, from the most brutal terror to granting privileges, yielded a result equal to zero. However, this was clear much earlier, even when the denationalization was in full swing. A report by the military governor-general in Nis on 20 November 1916 says: "the majority of the population in this part of the former Serbia, now the Morava Military Inspection Area, consider themselves to be Serbs," in fact "they are purely Serbian or consider themselves as such." An analysis of the census conducted in the summer of 1916, from county to county, was in full compliance with the expressed point of view: for Vranje and its surroundings, "it would be naive to believe that the population of Vranje was Bulgarian and could be assimilated anytime soon"; for Pirot and its surroundings, "the population of the district [...] today is Serbianized and feels itself to be Serbian, lives with Serbian feelings patiently waiting for the establishment of the kingdom of Serbia"; in Niš and its surroundings, "according to statistics from May of this year, the population of the district consists of 170,000 Serbs, 31 Bulgarians, the rest being other nationalities." ${ }^{34}$

The failure of Bulgarization was also fully evident in school and educational policy. On 22 July 1916, the Austro-Hungarian Consul in Niš, Kolrus, reported that the Bulgarians had persuaded students to express,

31 KA-Wien, Op. Abt. Nr. 40904.

32 Ibidem, as well in several documents from: HHStA-Wien, PA I, K. 976 и 977.

33 HHStA-Wien, PA I, K. 975, report from Niš on 6 October 1918.

34 KA-Wien, Op. Abt. Nr. 40904. 
at a school performance, joy over becoming Bulgarians again, but "the rehearsal turned out unfavorably for the Bulgarians" as the parents cried when they saw what was being done to their children. ${ }^{35} \mathrm{~A}$ particularly distinctive case was presented in the report of Vice-Consul Has written on 24 February 1918: on Saturday 16 of February, a "propaganda film show" was performed for students of grammar school in Niš and "various landscapes of 'Bulgarian Pomoravlje'" were presented. Then the principal told the students "using the usual phrases" that the "Morava region has always been Bulgarian and must remain Bulgarian," and that the students had to keep in mind that "their parents have always been Bulgarians and now, after the liberation, will remain so forever." Has writes further: "On this, one boy shouted: 'our parents have always been Serbs and they will always remain that'. There was a commotion, and the children erupted with stormy shouting of 'long live Serbia!' The principal requested the names of the protesters, but no one would tell him. The next day, an investigation was carried out, but with no results. As the principal was lecturing on politics again, an open discussion took place in which the children taught him better. They openly said that they were asked the impossible if required to feel as Bulgarians. The father of one of them is a Serbian officer, the father of another one is in a Bulgarian prison, the father of a third one was shot by Bulgarians upon the fall of Niš, etc. The principal did not know what to say, so he took the usual Bulgarian ultima ratio warning the students on a danger they were putting their families in, as they would be interned. At that point the discussion was over." Has remarked: "This case sheds a different light on the repeated claims made by the press that the entire population, and especially the youth, were celebrating their Bulgarian liberators, as these children, the whole population, is aware of its nationality, although it is not shown so openly [...]. In practice this is not a historical quibble but the conviction of the population, clearly reflected in the hasty manifestations of the school youth." 36

All the other imposed measures resulted only in convincing the Bulgarian allies that Bulgarization was having little success. In a report on 26 August 1917, Count Otto von Czernin, the representative of the Dual Monarchy in Sofia, wrote to his brother Ottokar that the Bulgarian claims should be questioned as the "population of the Pirot district [...], with the

35 HHStA-Wien, PA I, K. 976; here are the reports of Kolrus, Has and Otto Czernin that are mentioned later in the text.

36 HHStA-Wien, PA I, K. 976; here are the reports of Kolrus, Has and Otto Czernin that are mentioned later in the text. 
exception of a few elderly people, feels it is Serbian," that he had confidential information that the residents of Niš were "very bitter against the Bulgarians," that "barely anyone reads the Moravski Glas, the Bulgarian newspaper founded for propaganda purposes," that "only some citizens or merchants who only wish to benefit from the present circumstances, could be considered as Bulgarians," that the locals do not take seriously the Bulgarian aspirations to Niš, etc. ${ }^{37}$

In January of 1918, Vice-Consul Has reported that some residents of Zaječar and Brza Palanka, despite the pressure, refused to sign statements saying they were Bulgarians. The local authorities in Niš, also, were expecting conflicts as a result of the orders to collect signatures since "just today the largest and most influential families, mostly commercial, have declared that they would not sign" such a statement (because they were convinced that "if they participated in an anti-Serb incident, their future would be ruined"), so some traders "have already informed of their sickness in order to get consent for their absence when the day of such manifestation comes," Niš Mayor Strabanov, brought over from Sofia, believed that the declaration of nationality could not be extorted from the citizens of Niš and that this step could only crate problems to the occupying authorities. On 8 August 1918, Has reported that "to this day the Bulgarians have failed" to get even a formal statement from residents of Niš that they are Bulgarians, in spite "numerous attempts." In Niš, an opinion prevailed that the Bulgarian occupation was only "a short transitional period" and that "the Serbs would come back," which completely differed from the Bulgarian press releases, and "people were firmly convinced that Niš would belong to Serbia again." 38

In the Macedonia Military Inspection Area, things were not going too well for the occupation authorities either. The Bulgarization propaganda campaign had to be constantly reinforced, becoming a real psychological terror. Phrases with no content, regarded as if they were sacred, dominated public life suppressing all opinions except those preached by the authorities. In June of 1918 the Austro-Hungarian Consul in Skopje noted: "The basic term in use is the term 'great'. The great history of Bulgaria, the greatness of the Old Bulgarian Empire, the great Bulgarian Army, also the great Bulgarian culture [...] etc., etc., represent subject of almost all public appearances [...]."39

37 Ibidem.

38 Ibidem, K. 975, report from Skopje on 9 Jun 1918.

39 Ibidem. 
For the Kingdom of Serbia the Great War was a fight to the death with regard to the aspirations and plans of the invading countries and their actions during the occupation of Serbia's territory. The Sofia agreement stipulated the destruction of the Kingdom of Serbia as an independent state. The Central Powers attempted to divide Serbia's territories once and for all. However, the tide of the war turned against them!

\section{Summary}

In the occupied part of Serbia, the Bulgarians structured their internal organization to match the provisional conditions imposed by the war, but also with regard to the intention of keeping these territories permanently. It was a combined military and civilian administration. The military role was crucial and the highest military and civilian authority was in the hands of the military governor-general. The bureaucracy, especially the managerial staff, as well as the mayors came from Bulgaria. In the course of the war, although the Hague Conventions specifically protected the civilian population, private property, state property, the Bulgarian state violated articles 46,47 and 56 and selectively applied articles 45 and $52 \mathrm{~b}$ of the Hague Convention.

The Bulgarian occupation authorities endeavored to submit the Serbs and turn them into "good" Bulgarians. In doing so, the occupation authorities applied the following methods: internment, Bulgarization, and ruthless economic exploitation. In the area of Niš and in Macedonia, deportations began immediately. Deportees were priests, teachers, doctors, deputies, etc. The use of Serbian personal names, language and script was forbidden. Regulations were issued ordering the confiscation of textbooks and teaching materials in the Serbian language, Serbian books, pictures and maps at public institutions, bookstores, and private homes. The occupation officials received orders on the "absolute prohibition of any correspondence in the Serbian language." Parishes of Serbian priests were assigned to Bulgarian priests and the occupied areas were placed under the direct authority of the Bulgarian Church. Churches and monasteries were desecrated and looted. Schools in Bulgarian language with Bulgarian teaching staff were established. The Bulgarian occupation authorities exercised preventive punishment over the occupied population for three years, demonstrating power and brutality. It was an unsuccessful attempt to turn the residents of the Kingdom of Serbia into "good Bulgarian citizens." 


\section{Sources and Literature}

- $\quad$ Politisches Archiv des Auswartigen Amtes in Bonn. Oxfort.

- Haus-, Hof- und Staatsarchiv- Wien. Politische Abteilung.

- Documents relatifs aux violations des conventions de La Haye et du Droit international en general commises de 1915-1918 par les Bulgares en Serbie occuppée, 1-3. Paris: Français Cartonne, 1919.

- $\quad$ The Enemy in Serbia, Documents Relative to the Bulgarian Atrocities 19151918. Paris, 1919.

- $\quad$ Avramovski, Živko. Ratni ciljevi Bugarske i Centralne sile 1914-1918. Beograd: Institut za savremenu istoriju, 1985.

- Avramovski, Živko. „Bugarske pretenzije na aneksiju delova Kosova u prvom svetskom ratu (1915-1916)“,Jugoslovensko-bugarski odnosi u XXveku 2,1982, 110-151. (cyrillic)

- $\quad$ Lalkov, Milčo. Balkanskata politika na Avstro-Ungarija 1914-1917. Sofija: Nauka i izkustvo, 1983. (cyrillic)

- $\quad$ Mitrović, Andrej. „Tajni ugovor između Centralnih sila i Bugarske od 6. septembra 1915". Međunarodni problemi 3-4, 1978, 47-65.

- $\quad$ Mitrović, Andrej. Srbija u Prvom svetskom ratu. Beograd: Srpska književna zadruga, 1984. (cyrillic)

- $\quad$ Mitrović, Andrej. Prodor na Balkan. Beograd: Zavod za udžbenike, 1981.

- $\quad$ Mitrović, Andrej. „Stvaranje nemačke okupacione zone i austrougarske uprave u Srbiji (jesen 1915 - proleće 1916)“. Istorijski glasnik, br. 1-2,1977. (cyrillic)

- $\quad$ Milojević, Momir. „Povrede Haških i Ženevskih konvencija u Srbiji“. Srbija 1917. godine, ur. Slavenko Terzić, 21-35. Beograd: Istorijski institut SANU, 1988. (cyrillic)

- $\quad$ Perović, Milivoje. Toplički ustanak 1917. Beograd: Slovo ljubve, 1971. (cyrillic)

- $\quad$ Reis, R. A., A. Bonnassieux. Requisitoire contre la Bulgarie. Paris: Librairie Bernard Grasset, 1919.

- $\quad$ Uwe, Friedrich Wolfgang. "Bulgarien und die Mächte 1913-1915. Ein Beitrag zur Weltkriegs- und Imperialismusgeschichte", Quellen und Studien zur Geschichte des östlichen Europa, Bd. 21. Stuttgart, 1985. 


\title{
Резиме
}

Божица Б. Младеновић

\section{Бугарски окупациони режим у Србији 1915-1918. у светлу аустроугарских докумената}

\begin{abstract}
АПстРАКТ: Овај рад говори о успостављању и кључним аспектима бугарског окупационог система у Краљевини Србији од 1915. до 1918. Утемељен је на примарним историјским изворима немачког и аустријског порекла и постојећој литератури. Основне карактеристике окупационих власти, које су формирале две војно-инспекцијске области: Мораву и Македонију, анализирају се кроз призму кршења Конвенције и закона и обичаја ратовања, познате под називом Хашке конвенције из 1908. године.

КљУчнЕ РЕчи: Србија 1915-1918, бугарска окупација, Војно-инспекцијска област Морава, Војно-инспекцијска област Македонија, бугаризација (денационализација), економска експлоатација
\end{abstract}

Бугари су у окупираном делу Србије образовали организацију власти која је одговарала привременим условима наметнутим ратом, али и намери да те територије трајно задрже. То је била комбинација војне и цивилне управе. Војна управа је била пресудна, и највиша војна и цивилна власт била је у рукама војног гувернера. Бирократија, посебно руководеће особље, као и градоначелници долазили су из Бугарске. Током рата, иако су Хашке конвенције посебно штитиле цивилно становништво, приватну својину, државну имовину, бугарска држава је прекршила њихове чланове 46, 47 и 56 и селективно примењивала чланове 45 и 52 b.

Бугарске окупационе власти су се трудиле да потчине Србе и претворе их у „добре“ Бугаре. При томе су примењивале следеће методе: интернирање, бугаризацију и безобзирну економску експлоатацију. На подручју Ниша и Македоније депортације су одмах почеле. Депортовани су били свештеници, наставници, лекари, посланици и др. Употреба српских личних имена, језика и писма била је забрањена. Донета је уредба којом се наређује одузимање уџбеника и наставног материјала на српском језику, српских књига, слика 
и карата у јавним установама, књижарама и приватним кућама. Носиоцима окупационе власти послата су наређења о „апсолутној забрани кореспонденције на српском језику“. Парохије српских свештеника додељене су бугарским свештеницима, а окупирана подручја су стављена под директну власт бугарске цркве. Цркве и манастири су оскрнављени и опљачкани. Осниване су школе на бугарском језику са бугарским наставним особљем. Окупационе власти су три године превентивно кажњавале окупирано становништво, показујући снагу и бруталност. Био је то неуспешан покушај да становници Краљевине Србије постану добри грађани Бугарске. 